Proc. of the International Conference on Mechanochemistry and Mechanical Alloying, Kraków, Poland, June 22-26, 2014

\title{
Study of the Mechanochemical Reduction of Ilmenite Concentrate by Addition of Aluminum
}

\author{
M. Achimovičová ${ }^{a, b, *}$, E. $\operatorname{Gock}^{a}$, E. Turianicová ${ }^{b}$, N.G. Kostova ${ }^{c}$, N. Velinov ${ }^{c}$, \\ M. KAŇUCHOVÁ ${ }^{d}$ AND P. BALÁZ̆ ${ }^{b}$ \\ ${ }^{a}$ Institute of Mineral and Waste Processing, Waste Disposal and Geomechanics, Technical University-Clausthal, \\ Walther-Nernst 9, Clausthal, Germany \\ ${ }^{b}$ Institute of Geotechnics, Slovak Academy of Sciences, Watsonova 45, Košice, Slovakia \\ ${ }^{c}$ Institute of Catalysis, Bulgarian Academy of Sciences, Acad. Georgi Bonchev 11, Sofia, Bulgaria \\ ${ }^{d}$ Faculty of Mining, Ecology, Process Control and Geotechnology, Technical University-Košice, \\ Letná 9, Košice, Slovakia
}

\begin{abstract}
Mechanochemical reduction of ilmenite concentrate $\left(\mathrm{FeTiO}_{3}\right)$ with elemental aluminum powder was performed by high-energy milling in an industrial eccentric vibratory ball mill ESM 656-0.5 ks (Siebtechnik, Germany). The mechanochemically reduced ilmenite with various times of milling was characterized by X-ray diffraction analysis, which confirmed the presence of the $\mathrm{Al}_{2} \mathrm{O}_{3}$ and $\mathrm{Fe}_{2} \mathrm{Ti}$ phases after 120 min of milling. Thermal analysis evidenced the completion of a mechanochemical reduction during milling. After 360 min of milling, the $\mathrm{Fe}_{2} \mathrm{Ti}$ phase decomposed to $\alpha-(\mathrm{Fe}, \mathrm{Ti})$ alloy, which was proven by ${ }^{57} \mathrm{Fe}$ Mössbauer spectroscopy. X-ray photoelectron spectroscopy detected the amorphous $\mathrm{TiO}$ phase in product after mechanochemical reduction, which is in accordance with thermodynamic prediction. Decreasing of specific surface area after $60 \mathrm{~min}$ of milling resulted from growing layers of the solid products of $\mathrm{FeTiO}_{3}$ mechanochemical reduction.
\end{abstract}

DOI: 10.12693/APhysPolA.126.867

PACS: 77.84.Cg, 81.20.Wk, 81.20.Ev, 82.33.Pt

\section{Introduction}

The mineral ilmenite, $\mathrm{FeTiO}_{3}$, belongs to a group of titanium-containing minerals and its world's production reached 5.19 million metric tons in 2009 [1]. At present, $\mathrm{FeTiO}_{3}$ is the most important source of titanium for the titanium industry. The preparation of metals and alloys by the reduction of their salts with metals has been described in pyrometallurgy [2]. The method is characterized by the fact that the reducing metal is converted by high temperature to a solid or a liquid product and not to a gas as in other reducing processes. The main parameters of these so-called metallothermic reactions are the contact surfaces of reacting particles and their area, where the solid-state reaction starts [3]. By applying mechanical activation, this parameter can be increased. It has been shown that the coefficient of the diffusivity of solids can be enhanced up to 3 orders $[4,5]$. Both reactants and products are evenly dispersed through the reaction volume at a later stage of the redox reaction. The particles decrease to nanometer-sized crystallites and are brought into intimate contact, thereby greatly increasing the reacting areas. The high defect densities induced in the powder further increase the reaction rates by providing a short circuit diffusion path [6]. The mechanochemical reduction of $\mathrm{FeTiO}_{3}$ with aluminum

\footnotetext{
* corresponding author; e-mail:

marcela.achimovicova@tu-clausthal.de
}

and magnesium in a laboratory ball mill has been described by Welham $[7,8]$. He demonstrated that the products of a mechanochemical reaction were nanocrystalline $\mathrm{TiAl}_{3}, \mathrm{Fe}_{3} \mathrm{Al}_{13}$, and $\mathrm{Al}_{2} \mathrm{O}_{3}$ after $100 \mathrm{~h}$ of milling.

In this paper, we followed a course of ilmenite mechanochemical reduction with elemental aluminum, in dependence on the milling time at ambient temperature in an industrial eccentric vibratory ball mill. We studied the physical, chemical, structural, and thermal changes of mechanochemically reduced ilmenite concentrate.

\section{Experimental}

\subsection{Material}

The investigations were carried out with ilmenite concentrate $\left(>95 \% \mathrm{FeTiO}_{3},<5 \% \mathrm{SiO}_{2}\right.$ ) of Russian origin (GMD, Mineral Trade Company). The chemical composition was as follows: $34.43 \% \mathrm{Fe}, 30.02 \% \mathrm{Ti}, 0.76 \% \mathrm{Si}$, $0.47 \% \mathrm{Mg}, 0.42 \% \mathrm{Al}, 0.34 \% \mathrm{Mn}, 0.11 \% \mathrm{Zn}, 0.09 \% \mathrm{Ca}$, $0.07 \% \mathrm{Cr}, 0.06 \% \mathrm{Co}, 0.03 \% \mathrm{Ba}, 31.63 \% \mathrm{O}$ and $1.57 \%$ insoluble rest.

\subsection{Mechanical activation and mechanochemical reduction}

Mechanical activation of $\mathrm{FeTiO}_{3}$ was performed in an industrial eccentric vibratory ball mill ESM 656-0.5 ks (Siebtechnik, Germany) in air atmosphere and room temperature for 5-360 min with $100 \mathrm{~g} \mathrm{FeTiO}_{3}$ per charge. The mechanochemical reduction of $\mathrm{FeTiO}_{3}$ with elemental aluminum $\mathrm{Al}$ (99.5\%, Alfa Aesar, Germany) as a reductant was performed in the same mill in an argon 
atmosphere for 5-360 min with $100 \mathrm{~g} \mathrm{FeTiO}_{3}$ and $\mathrm{Al}$ mixture per charge. The other conditions were the following: 51 steel satellite milling chamber, steel balls with a diameter of $30 \mathrm{~mm}$ with a total mass $17 \mathrm{~kg}$, rotational speed of the eccenter $960 \mathrm{rpm}$. This type of mill is currently used in an animal food industry and was developed by Gock and Kurrer [9, 10]. The feed for mechanochemical reduction was the stoichiometric mixture of $\mathrm{FeTiO}_{3}: \mathrm{Al}=0.49 \mathrm{~mol}: 0.96 \mathrm{~mol}$ corresponding to the total mass $100 \mathrm{~g}$ of the precursors. According to the thermodynamic calculation using FactSage with FactPS database (no solution phases included) it was found that $\mathrm{FeTiO}_{3}$ is thermodynamically unstable in the presence of $\mathrm{Al}$, and the $\mathrm{Al}_{2} \mathrm{O}_{3}$ phase is already formed at ambient temperature. Subsequently, $\mathrm{TiAl}, \mathrm{TiO}$, and $\mathrm{Fe}_{2} \mathrm{Ti}$ are stable phases up to $1057^{\circ} \mathrm{C}$. With increasing temperature, TiAl phase decomposes and FeTi phase is developing. Between $1100{ }^{\circ} \mathrm{C}$ and $1700{ }^{\circ} \mathrm{C}$, the following phases are in equilibrium: $\mathrm{Al}_{2} \mathrm{O}_{3}, \mathrm{TiO}, \mathrm{Fe}_{2} \mathrm{Ti}$, and FeTi.

\subsection{Characterization techniques}

A specific surface area was measured by the low temperature nitrogen adsorption method using a NOVA Station A surface area analyzer (Quantachrome Instruments, USA). Differential thermal analysis (DTA) was performed using the STA 449 F3 Jupiter (Netzsch, Germany) under dynamic conditions in $\operatorname{Ar}\left(50 \mathrm{~cm}^{3} / \mathrm{min}\right)$ with a heating rate of $10^{\circ} \mathrm{C} / \mathrm{min}$. The phase composition identification was performed by X-ray diffractometry (XRD) with an X'Pert PW 3040 MPD diffractometer (Phillips, Germany) working in the $2 \theta$ geometry with $\mathrm{Cu} K_{\alpha}$ radiation. The Mössbauer measurements (MS) were performed with a Wissel (Wissenschaftliche Elektronik GmbH, Germany) electromechanical spectrometer working in a constant acceleration mode. A ${ }^{57} \mathrm{Co} / \mathrm{Rh}$ source and a $\alpha$-Fe standard were used. The experimentally obtained spectra were fitted with CONFIT2000 software [11]. The surface chemical analysis was carried out by X-ray photoelectron spectroscopy (XPS) with a SPECS XPS instrument equipped with PHOIBOS 100 SCD and non-monochromatic X-ray source. The spectra were acquired at a basic pressure of $2 \times 10^{-8}$ mbar with $\mathrm{Mg} K_{\alpha}$ excitation at $10 \mathrm{kV}(150 \mathrm{~W})$. The data were analyzed by SpecsLab2 CasaXPS software.

\section{Results and discussion}

It is generally known that mechanical activation results in a crystal lattice distortion of mineral and an increase in the specific surface area [5]. The specific surface area of mechanically activated $\mathrm{FeTiO}_{3}$ has increased up to $60 \mathrm{~min}$ of milling and reached the value of $10 \mathrm{~m}^{2} / \mathrm{g}$ (Fig. 1). A further decrease in the specific surface area values over the milling time is caused by the recombination of the fine grains of $\mathrm{FeTiO}_{3}$. The specific surface area of mechanically reduced $\mathrm{FeTiO}_{3} / \mathrm{Al}$ mixtures has only increased to $30 \mathrm{~min}$ of milling and reached the maximal value $3.6 \mathrm{~m}^{2} / \mathrm{g}$, because during the first $30 \mathrm{~min}$ of milling, the $\mathrm{Al}$ particles become ductile and probably cold weld each other along with $\mathrm{FeTiO}_{3}$ particles. The plastic deformation makes particles hard and brittle and, therefore, the fracture mechanism activates together with a mechanochemical reduction of $\mathrm{FeTiO}_{3}$ and the growing layers of solid products. It results in the gradual decrease of the specific surface area after $60 \mathrm{~min}$ of milling.

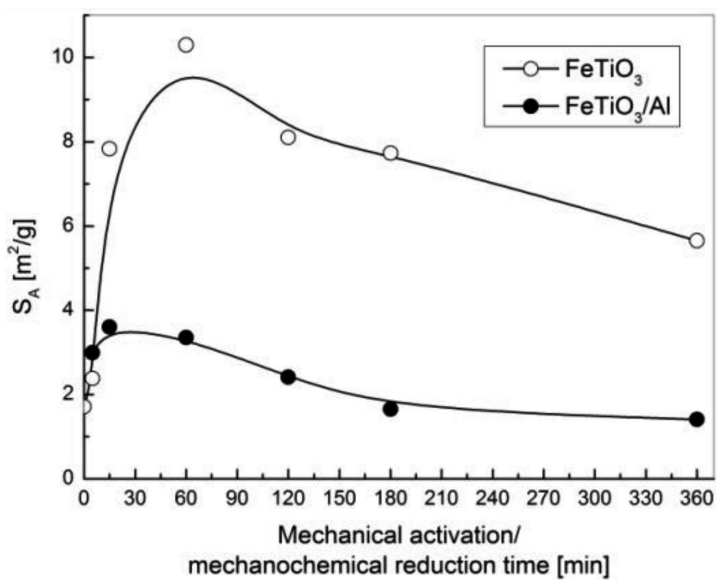

Fig. 1. Specific surface area of the mechanically activated $\mathrm{FeTiO}_{3}$ and mechanochemically reduced $\mathrm{FeTiO}_{3} / \mathrm{Al}$ mixture for various times of milling.

Expected chemical reaction (mechanochemical reduction) and structural changes in unmilled and milled $\mathrm{FeTiO}_{3} / \mathrm{Al}$ powder mixtures have been monitored by DTA. The analyses of milled $\mathrm{FeTiO}_{3} / \mathrm{Al}$ mixtures have shown that there were no mass changes $(<6.5 \%)$ up to $1200^{\circ} \mathrm{C}$, confirming the solid-state nature of mechanochemical reduction. The DTA curves of the $\mathrm{FeTiO}_{3} / \mathrm{Al}$ mixtures for various times of milling are shown in Fig. 2. The curve of the unmilled $\mathrm{FeTiO}_{3} / \mathrm{Al}$ mixture shows an endotherm at $660^{\circ} \mathrm{C}$ for $\mathrm{Al}$ melting and an exotherm due to a reaction at $1015^{\circ} \mathrm{C}$, which is in accordance with [7]. After 60 min of milling, $\mathrm{Al}$ is consumed below its melting point and two exotherm peaks appeared at a lower temperature $\left(625^{\circ} \mathrm{C}, 775^{\circ} \mathrm{C}\right)$. The DTA curves for $120 \mathrm{~min}$ and $360 \mathrm{~min}$ of milling show no peaks, thus no thermal activity, which proves the completion of mechanochemical reduction during milling.

XRD patterns of unmilled and milled $\mathrm{FeTiO}_{3} / \mathrm{Al}$ mixtures are shown in Fig. 3. It is clearly seen that after 60 min of milling there is no evidence of mechanochemical reduction because only broadened peaks for Al (JCPDS PDF 004-0787) and $\mathrm{FeTiO}_{3}$ (JCPDS PDF 003-0793) are present. After 120 min of milling, new phases appeared: $\mathrm{Al}_{2} \mathrm{O}_{3}$ (JCPDS PDF 042-1468) and $\mathrm{Fe}_{2} \mathrm{Ti}$ (JCPDS PDF 003-1040). This means that a mechanochemical reaction between $\mathrm{Al}$ and $\mathrm{FeTiO}_{3}$ precursors was accomplished during milling. The missing $\mathrm{TiO}$ phase is probably amorphous, hence invisible. Longer 360 min milling has caused the $\mathrm{Fe}_{2} \mathrm{Ti}$ phase to disappear and a new ambiguous Fe phase (JCPDS PDF 006-0696) was found. According to Guedea and co-authors, the milling of $\mathrm{Fe}_{2} \mathrm{Ti}$ leads to its decomposition and formation of a material with a cubic (bcc) structure consistent with the solid solution of $\mathrm{Ti}$ in $\alpha$-Fe [12]. 


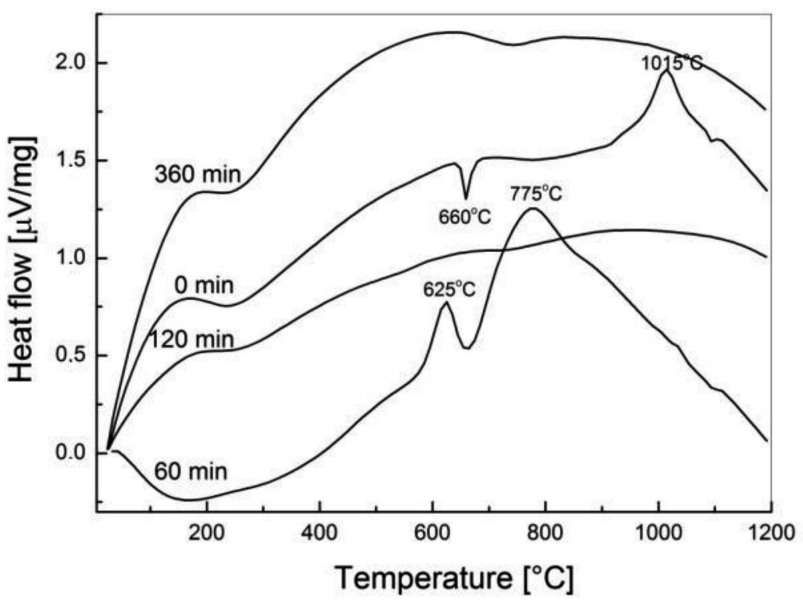

Fig. 2. DTA curves of $\mathrm{FeTiO}_{3} / \mathrm{Al}$ mixtures for various times of milling.

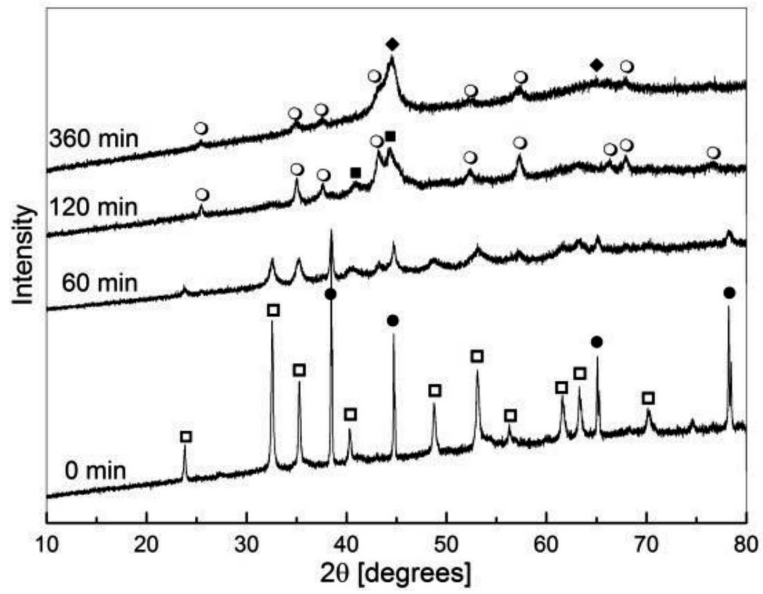

Fig. 3. X-ray diffraction patterns of $\mathrm{FeTiO}_{3} / \mathrm{Al}$ mixtures for various times of mechanochemical reduction, $\square \mathrm{FeTiO}_{3}, \bullet \mathrm{Al}, \bigcirc \mathrm{Al}_{2} \mathrm{O}_{3}, \mathbf{\square} \mathrm{Fe}_{2} \mathrm{Ti}, \diamond \mathrm{Fe}$.

MS is a very sensitive and versatile technique that can be used to give information about the chemical, structural, magnetic and time-dependent properties of a material and is widely used to complement XRD analysis. The ${ }^{57} \mathrm{Fe}$ Mössbauer spectrum of unmilled $\mathrm{FeTiO}_{3}, 0$ min is fitted with two doublets model (Fig. 4). The results of fitting in Table evidently have shown the presence of $\mathrm{Fe}$ in oxidation states $\mathrm{Fe}^{3+}(\delta=0.35 \mathrm{~mm} / \mathrm{s}, \Delta=0.47 \mathrm{~mm} / \mathrm{s})$ and $\mathrm{Fe}^{2+}(\delta=1.09 \mathrm{~mm} / \mathrm{s}, \Delta=0.68 \mathrm{~mm} / \mathrm{s})$. The calculated parameters of doublets correspond to nonstoichiometric ilmenite $\mathrm{Fe}_{1+x} \mathrm{Ti}_{1-x} \mathrm{O}_{3}$ [13]. The relative weight of $\mathrm{Fe}^{3+}$ component $(\mathrm{G})$ is $25 \%$. In the milled $\mathrm{FeTiO}_{3} / \mathrm{Al}$ mixtures, the components ratio $\mathrm{Fe}^{3+} / \mathrm{Fe}^{2+}$ is higher than this ratio in unmilled $\mathrm{FeTiO}_{3}$ (Table). The MS spectrum of $\mathrm{FeTiO}_{3} / \mathrm{Al}, 60$ min consists of the same components as sample $\mathrm{FeTiO}_{3}, 60 \mathrm{~min}$. The ratio of the relative weights of doublets $\mathrm{Fe}^{3+} / \mathrm{Fe}^{2+}$ is calculated as $20 / 78$ in the sample with $\mathrm{Al}$, while in $60 \mathrm{~min}$ milled sample without $\mathrm{Al}$ it is $35 / 61$. In the spectrum of $\mathrm{FeTiO}_{3} / \mathrm{Al}, 120 \mathrm{~min}$ a new doublet component appeared with the parameters

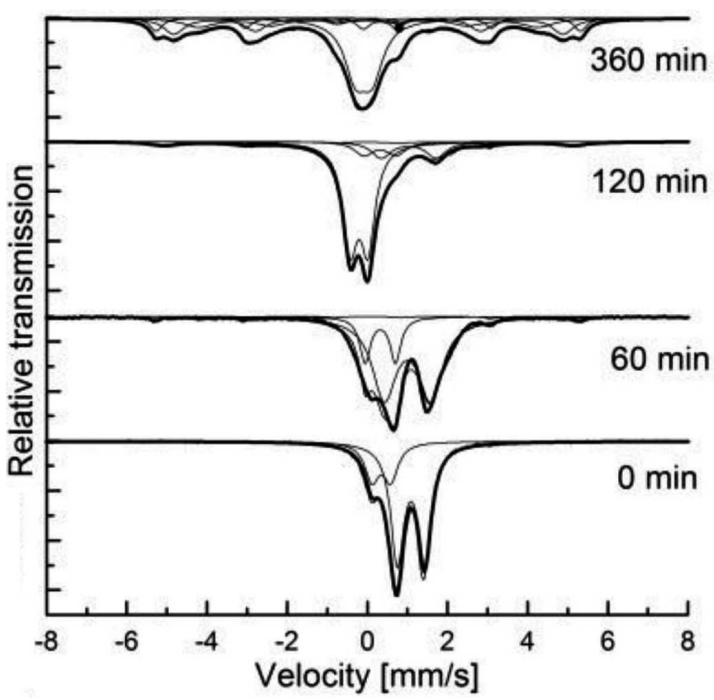

Fig. 4. ${ }^{57} \mathrm{Fe}$ Mössbauer spectra of unmilled $\mathrm{FeTiO}_{3}$ and $\mathrm{FeTiO}_{3} / \mathrm{Al}$ mixtures for various times of mechanochemical reduction.

TABLE

Calculated Mössbauer parameters of investigated samples: isomer shift $(\delta)$, quadrupole splitting $(\Delta)$, effective internal magnetic field $(\mathrm{B})$, line widths $\left(\Gamma_{\exp }\right)$, and relative weight $(\mathrm{G})$ of the partial components in the spectra

\begin{tabular}{|c|c|c|c|c|c|c|}
\hline $\begin{array}{l}\text { Sample, } \\
\text { milling time }\end{array}$ & Components & {$\left[\begin{array}{c}\delta \\
\left.\frac{\mathrm{mm}}{s}\right]\end{array}\right.$} & $\begin{array}{c}\Delta \\
{\left[\frac{\mathrm{mm}}{s}\right]}\end{array}$ & $\begin{array}{c}B \\
{[\mathrm{~T}]}\end{array}$ & $\begin{array}{l}\Gamma_{\exp } \\
{\left[\frac{\mathrm{mm}}{s}\right]}\end{array}$ & $\begin{array}{c}G \\
{[\%]}\end{array}$ \\
\hline \multirow{2}{*}{$\begin{array}{l}\mathrm{FeTiO}_{3}, \\
0 \mathrm{~min}\end{array}$} & Db1-Fe ${ }_{1+x} \mathrm{Ti}_{1-x} \mathrm{O}_{3}-\mathrm{Fe}^{3+}$ & 0.35 & 0.47 & - & 0.43 & 25 \\
\hline & $\mathrm{Db} 2-\mathrm{Fe}_{1+x} \mathrm{Ti}_{1-x} \mathrm{O}_{3}-\mathrm{Fe}^{2+}$ & 1.09 & 0.68 & - & 0.40 & 75 \\
\hline \multirow{3}{*}{$\begin{array}{l}\mathrm{FeTiO}_{3}, \\
60 \mathrm{~min}\end{array}$} & $\mathrm{Sx}-\alpha-(\mathrm{Fe}, \mathrm{Ti})-\mathrm{Fe}^{0}$ & 0.00 & 0.00 & 32.8 & 0.31 & 4 \\
\hline & $\mathrm{Db} 1-\mathrm{Fe}_{1+x} \mathrm{Ti}_{1-x} \mathrm{O}_{3}-\mathrm{Fe}^{3+}$ & 0.36 & 0.75 & - & 0.40 & 35 \\
\hline & $\mathrm{Db} 2-\mathrm{Fe}_{1+x} \mathrm{Ti}_{1-x} \mathrm{O}_{3}-\mathrm{Fe}^{2+}$ & 1.02 & 1.10 & - & 0.71 & 61 \\
\hline \multirow{3}{*}{$\begin{array}{l}\mathrm{FeTiO}_{3} / \mathrm{Al}, \\
60 \mathrm{~min}\end{array}$} & $\mathrm{Sx}-\alpha-(\mathrm{Fe}, \mathrm{Ti})-\mathrm{Fe}^{0}$ & 0.00 & 0.00 & 32.9 & 0.30 & 2 \\
\hline & Db1- $\mathrm{Fe}_{1+x} \mathrm{Ti}_{1-x} \mathrm{O}_{3}-\mathrm{Fe}^{3+}$ & 0.32 & 0.76 & - & 0.32 & 20 \\
\hline & $\mathrm{Db} 2-\mathrm{Fe}_{1+x} \mathrm{Ti}_{1-x} \mathrm{O}_{3}-\mathrm{Fe}^{2+}$ & 1.00 & 1.16 & - & 0.72 & 78 \\
\hline \multirow{4}{*}{$\begin{array}{l}\mathrm{FeTiO}_{3} / \mathrm{Al} \text {, } \\
120 \mathrm{~min}\end{array}$} & $\mathrm{Sx}-\alpha-(\mathrm{Fe}, \mathrm{Ti})-\mathrm{Fe}^{0}$ & 0.00 & 0.02 & 31.7 & 0.88 & 9 \\
\hline & $\mathrm{Db} 1-\mathrm{Fe}_{2} \mathrm{Ti}-\mathrm{Fe}^{0}$ & -0.21 & 0.44 & - & 0.44 & 65 \\
\hline & $\mathrm{Db} 2-\mathrm{Fe}_{1+x} \mathrm{Ti}_{1-x} \mathrm{O}_{3}-\mathrm{Fe}^{3+}$ & 0.32 & 0.81 & - & 0.56 & 11 \\
\hline & Db3-Fe $1+x \mathrm{Ti}_{1-x} \mathrm{O}_{3}-\mathrm{Fe}^{2+}$ & 1.03 & 1.37 & - & 0.59 & 15 \\
\hline \multirow{6}{*}{$\begin{array}{l}\mathrm{FeTiO}_{3} / \mathrm{Al}, \\
360 \mathrm{~min}\end{array}$} & $\mathrm{Sx} 1-\alpha-(\mathrm{Fe}, \mathrm{Ti})-\mathrm{Fe}^{0}$ & 0.02 & 0.00 & 32.9 & 0.37 & 11 \\
\hline & $\mathrm{Sx} 2-\alpha-(\mathrm{Fe}, \mathrm{Ti})-\mathrm{Fe}^{0}$ & 0.02 & 0.01 & 30.1 & 0.62 & 24 \\
\hline & $\mathrm{Sx} 3-\alpha-(\mathrm{Fe}, \mathrm{Ti})-\mathrm{Fe}^{0}$ & 0.04 & -0.02 & 26.3 & 0.94 & 20 \\
\hline & $\mathrm{Db} 1-\mathrm{Fe}_{2} \mathrm{Ti}-\mathrm{Fe}^{0}$ & -0.09 & 0.42 & - & 0.66 & 39 \\
\hline & $\mathrm{Db} 2-\mathrm{Fe}_{1+x} \mathrm{Ti}_{1-x} \mathrm{O}_{3}-\mathrm{Fe}^{3+}$ & 0.32 & 0.85 & - & 0.40 & 5 \\
\hline & $\mathrm{Db} 3-\mathrm{Fe}_{1+x} \mathrm{Ti}_{1-x} \mathrm{O}_{3}-\mathrm{Fe}^{2+}$ & 1.00 & 1.16 & - & 0.36 & 1 \\
\hline
\end{tabular}

$\delta=-0.21 \mathrm{~mm} / \mathrm{s}$ and $\Delta=0.44 \mathrm{~mm} / \mathrm{s}$, corresponding to $\mathrm{Fe}$ in the Laves phase $\mathrm{Fe}_{2} \mathrm{Ti}[12]$. The MS spectrum of $\mathrm{FeTiO}_{3} / \mathrm{Al}, 360 \mathrm{~min}$ is consisting of $50 \%$ magnetically ordered phase. This is in accordance with a previous investigation of the decomposition of the Laves phase $\mathrm{Fe}_{2} \mathrm{Ti}$ into $\alpha-(\mathrm{Fe}, \mathrm{Ti})$ alloys during milling [12] and confirm the rightness of X-ray diffraction pattern identification.

$\mathrm{X}$-ray photoelectron spectroscopy (XPS) is being used as a surface analytical tool to determine the surface chemical structures. The XPS survey spectra 
have demonstrated changes that are caused by a mechanochemical reduction in the surface stoichiometry of the products. The detailed spectral lines of Ti $2 p$ and Fe $2 p$ are shown in Fig. 5a and b. The binding energy

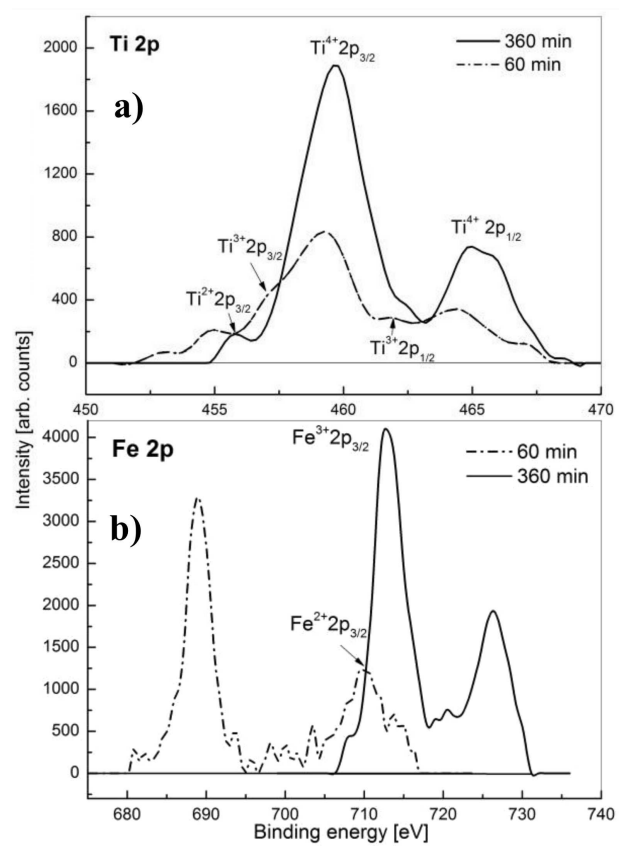

Fig. 5. (a) $\mathrm{Ti} 2 p$ XPS spectrum of $\mathrm{FeTiO}_{3} / \mathrm{Al}$ mixtures for 60 and 360 min of milling. (b) Fe $2 p$ XPS spectrum of $\mathrm{FeTiO}_{3} / \mathrm{Al}$ mixtures for 60 and 360 min of milling.

(BE) values $459.5 \mathrm{eV}$ and $465.2 \mathrm{eV}$ of the $\mathrm{Ti} 2 p_{3 / 2}$ and Ti $2 p_{1 / 2}$ lines correspond to $\mathrm{Ti}^{4+}$ doublet $[14,15]$. In addition, minor contributions from $\mathrm{Ti}^{2+}\left(\mathrm{BE}\left(\mathrm{Ti} 2 p_{3 / 2}\right)=\right.$ $456 \mathrm{eV})$ and $\mathrm{Ti}^{3+}\left(\mathrm{BE}\left(\mathrm{Ti} 2 p_{3 / 2}\right)=457.4 \mathrm{eV}\right.$ and $\mathrm{BE}(\mathrm{Ti}$ $\left.2 p_{1 / 2}\right)=463.1 \mathrm{eV}$ ) have appeared in the spectrum after mechanochemical reduction $\mathrm{FeTiO}_{3}$ with Al. This confirms the creation of the amorphous $\mathrm{TiO}$ phase according to thermodynamic prediction. The spectral lines of the Fe $2 p$ of $\mathrm{FeTiO}_{3} / \mathrm{Al}$ mixture after $60 \mathrm{~min}$ and $360 \mathrm{~min}$ of milling in Fig. 5b are in a different binding energy scale. According to $\mathrm{MS}$ data, $\mathrm{Fe}^{2+}$ ions in $\mathrm{FeTiO}_{3} / \mathrm{Al}$ mixture after 60 min of milling are more present as $\mathrm{Fe}^{3+}$ ions and, therefore, the $\mathrm{Fe}^{2+}$ peak $\left(\mathrm{BE}\left(\mathrm{Fe} 2 p_{3 / 2}\right)=709.5 \mathrm{eV}\right)$ has been clearly identified in the XPS spectrum. This peak is attributed to $\mathrm{FeO}$ [16]. The Fe $2 p$ spectrum after 360 min of milling is similar to the spectrum of $\mathrm{Fe}_{2} \mathrm{O}_{3}(\mathrm{BE}(\mathrm{Fe}$ $\left.2 p_{3 / 2}\right)=711.1 \mathrm{eV}$ ), which was prepared as a thin film grown on iron metal [16]. This evidences that $\alpha$-Fe as a product of mechanochemical reduction of ilmenite has oxidized in the surface layer. On the basis of our results the following formula for mechanochemical reduction of nonstoichiometric ilmenite by addition of aluminum can be suggested:

$$
\begin{aligned}
& \mathrm{Fe}_{1+x} \mathrm{Ti}_{1-x} \mathrm{O}_{3}+2 \mathrm{Al} \stackrel{\mathrm{Ar}, 360 \mathrm{~min}}{\longrightarrow} \\
& \quad \mathrm{Al}_{2} \mathrm{O}_{3}+(1-x) \mathrm{TiO}+(1+x) \alpha-(\mathrm{Fe}, \mathrm{Ti}) .
\end{aligned}
$$

\section{Conclusion}

Mechanochemical reduction of nonstoichiometric $\mathrm{FeTiO}_{3}$ with $\mathrm{Al}$ has been achieved after 120 min of milling by ambient temperature in the industrial eccentric vibratory ball mill. The product phases found from the thermodynamic calculations by $1100^{\circ} \mathrm{C}-1700^{\circ} \mathrm{C}$ $\left(\mathrm{Al}_{2} \mathrm{O}_{3}, \mathrm{TiO}, \mathrm{Fe}_{2} \mathrm{Ti}\right.$, and $\left.\mathrm{FeTi}\right)$ have already appeared after $360 \mathrm{~min}$ of mechanochemical reduction. The reaction mechanism of the mechanochemical reduction can probably be described with reaction (1). However, the more detailed study would be desirable, which is not the scope of this study. Such mechanochemical processing of ilmenite concentrate decreases the temperature and subsequently the time of thermal reduction of $\mathrm{FeTiO}_{3}$, which could be used in the titanium industry.

\section{Acknowledgments}

The authors would like to express their gratitude to the Deutsche Forschungsgemeinschaft for the financial support provided as a part of the Forschergruppe 1372/Titan and to Dr. M. Hampl for the thermodynamic calculations. The research was also supported by the Slovak Agency for Research and Development APVV (042311 and 0189-10), the Scientific Grant Agency VEGA $(1 / 1222 / 12,2 / 0027 / 14,2 / 0064 / 14)$, and the Bulgarian National Science Fund project (DNTS/Slovakia 01/3).

\section{References}

[1] W. Zhang, Z. Zhu, Ch. Cheng, Hydrometallurgy 108, 177 (2011).

[2] F. Habashi, Extractive Metallurgy, Vol. 3, Pyrometallurgy, Gordon and Breach, New York 1986.

[3] P.P. Budnikov, A.M. Ginstling, Reactions in Solid Mixtures, Strojizdat, Moscow 1971 (in Russian).

[4] P.J. Butyagin, V.S. Yuščenko, Kinetika i kataliz 27, 1035 (1987).

[5] P. Baláž, Mechanochemistry in Nanoscience and Minerals Engineering, Springer, Berlin 2008.

[6] G.B. Schaffer, P.G. Cormick, Metall. Trans. A 21A, 2789 (1990).

[7] N.J. Welham, J. Alloy. Comp. 270, 228 (1998).

[8] N.J. Welham, J. Alloy. Comp. 274, 260 (1998).

[9] E. Gock, K.E. Kurrer, Erzmetall 49, 434 (1996).

[10] E. Gock, K.E. Kurrer, Powder Technol. 105, 302 (1999).

[11] T. Žák, Y. Jirásková, Surf. Interface Anal. 38, 710 (2006).

[12] J. Guedea, H. Yee-Madeira, J.G. Cabanas, J. Mater. Sci. 39, 2523 (2004).

[13] Mössbauer Spectroscopy: Tutorial Book, Eds. Y. Yoshida, G. Langouche, Springer, Berlin 2013.

[14] A.F. Carley, P.R. Chalker, J.C. Rivieret, M. Wyn Roberts, J. Chem. Soc. Faraday Trans. 1 83, 351 (1987).

[15] J. Pouilleau, D. Devilliers, H. Groult, P. Marcus, J. Mater. Sci. 32, 5645 (1997).

[16] N.S. McIntyre, D.G. Zetaruk, Anal. Chem. 49, 1521 (1977). 